\title{
HORTICULTURAL SPECIES OF THE ISLAND OF LOKRUM IN THE PERIOD OF ARCHDUKE MAXIMILIAN OF HABSBURG (1859-1869) AND THEIR CURRENT STATE
}

\author{
HORTIKULTURNE VRSTE LOKRUMSKIH VRTOVA U PERIODU \\ NADVOJVODE MAKSIMILIJANA HABSBURŠKOG (1859.-1869.) \\ I NJIHOVO SADAŠNJE STANJE
}

Mara MARIĆ ${ }^{1}$ Ivana VITASOVIĆ-KOSIĆ2

\begin{abstract}
SUMMARY
This research, conducted within the ornamental gardens of the Island of Lokrum and based on the original archival documents from Trieste State Archives (AST) and Austrian State Archives (OeStA) in Vienna, was aimed at creating the first unique list of horticultural plant taxon planted on the island during the reign of the Archduke Ferdinand Maximilian Habsburg (1859-69). The research identified 213 taxa, including 184 species, 4 varieties, 8 hybrids and 17 cultivars. There were 193 allochthonous taxa, mostly originating from Central and South America (66), including 47 Asian species, 21 Australian species, 17 African species and 13 South American species. The Archive lists 20 taxa autochthonous in Croatia. While the number of the autochthonous taxa had apparently been higher, the historical documents have mostly recorded only the introduction of exotics. At that time, the following taxa were for the first time introduced in this part of the Adriatic, on the Island of Lokrum: Ananas comosus, Musa x paradisiaca, M. acuminata, Eucalyptus diversifolia, E. globulus, Araucaria araucana, A. columnaris, A. angustifolia, A. bidwillii, A. cunninghamii, Bougainvillea spectabilis and Citrus reticulata. At the location of the ornamental gardens, 51 ornamental allochthonous taxa and 20 autochthonous taxa were identified today. Within this number, only 21 allochthonous taxa and 9 autochthonous taxa remain present since the period of Maximilian. According to the 2018-2019 inventory, 71 taxa have been inventoried within the ornamental gardens on Lokrum, belonging to 43 families and 64 genera. Due to lack of intensive maintenance of the gardens, the majority of allochthonous, exotic species failed to survive within the autochthonous island vegetation. The list of taxa from Maximilian's gardens presented in this paper and retrieved from the archival sources, will be the starting point of the restoration process that awaits these gardens.
\end{abstract}

KEY WORDS: gardens of the Island of Lokrum, Dubrovnik, Maximilian von Habsburg, introduction, allochthonous horticultural species, botanical analysis

\section{INTRODUCTION} UVOD

The Island of Lokrum is located in direct vicinity of the historical core of Dubrovnik, only 600 metres away from the city port. The historical documents show that very early on, olive trees and vines were cultivated on the island, which was attributed to the Benedictine monks who resided there from $11^{\text {th }}$ century until late $18^{\text {th }}$ century (De Diversis 2007,

\footnotetext{
1'Assistant Professor Mara Marić, mara.maric@unidu.hr, University of Dubrovnik, Department for Mediterranean Plants, Marka Marojice 4, 20.000 Dubrovnik.

${ }^{2}$ Assistant Professor Ivana Vitasović Kosić, ivitasovic@agr.hr, University of Zagreb Faculty of Agriculture, Department of Agricultural Botany, Svetošimunska cesta 25, 10.000 Zagreb.
} 
Razzi 2011, The Statute of the City of Dubrovnik 1272). The very name of the island is considered to be derived from the Latin acrumen, acruminis (Skok 1950), which stands for fruit with a sharp or sour taste (Du Cange et al. 1883). It is assumed that the first introduction of citrus fruits in the area of the former Dubrovnik Republic took place on the Island of Lokrum (Šišić 1989a).

In the context of cultivation on the island, the most intensive period is the one of the second half of the $19^{\text {th }}$ century, when the island belonged to the Archduke Ferdinand Maximilian, member of Habsburg-Lothringen dynasty (18321867). The idea behind the acquisition of Lokrum was Maximilian's intention to introduce the exotic species collected in different parts of the world, which, due to adverse climatic conditions, could not thrive in the far north of the Adriatic, in the park of Maximilian's residence of Miramar (Dorsi 1986). The main idea was to carry out the introduction of exotic species within the natural autochthonous island vegetation, which would protect the exotics from the wind, salt sediment and temperature oscillations. At that time, it was a common practice in European imperial houses to cultivate exotic vegetation within protected facilities. A prominent European and Croatian botanist Roberto de Visiani made inventory of introduced horticultural species, evaluated those works at Lokrum as successful and gave references to continue the process (De Visiani 1863).

After that period there are no published works on the theme of monitoring of the introduced plants form Maximilian's time. During his visit to Lokrum in early $20^{\text {th }}$ century, Hirc (1905) pointed out that the plants were brought from Italy, Africa, India, Mexico and Brazil. Adamović (1911) wrote about poor maintenance of Maximilian's ornamental gardens. Neglected ornamental gardens from Maximilian's period were also the topic of a landscape architect Arnold

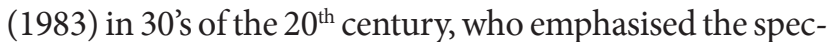
imens of Araucaria imbricata and A. excelsa.

One of the earliest typological classifications of gardens surrounding the monastery and Maximilian's mansion placing them to the category of ornamental gardens, is the one dating from 1959, made within the vegetation survey of the Island of Lokrum (Horvatić 1959). Since the 50's of the $20^{\text {th }}$ century, Šššć took interest in Lokrum as both, researcher and landscape designer (Šišić 1968, 1989a, 1989b, 2001, 2003a). The comparative analysis of exotic species of trees and shrubs of Lokrum and Arboretum Trsteno was made in 1997 (Đurasović 1997), but he also included the species in the Lokrum botanical garden. In 2002, an inventory of species was carried out within the Benedictine monastery and Maximilian's tower (Kapović 2002). Recently, horticultural and dendrological species within the monastery and the access section of Maximilian's gardens were inventoried (own research 2018, 2019). The project of the cultivated plants cadastre for the entire island has also been recently initiated (Hudina et al. 2019).
The objective of this paper is to use the available archival sources from the Trieste State Archives (AST) and Austrian State Archives (OeStA) in Vienna to create the first comprehensive list of horticultural species planted within the ornamental gardens of Lokrum in the period of Maximilian's reign (1859-1869) and determine the extent to which the horticultural species planted in Maximilian's time have been preserved until the present day. At the same time, this is the first research based on the archival data found on the species planted on the Island of Lokrum. For the purpose of this research, the horticultural species mean not only the lists of ornamental species of trees and shrubs, but also vegetables, fruits and herbaceous perennials planted in this period. Many of the ornamental species planted since that time belonged to the category of the so-called exotics. The phrase exotics or exotic species, which is not a botanical term or category, but a popular term, refers to foreign decorative species of unusual and attractive appearance, usually imported from tropical and subtropical areas (Kovačević 2012). For the purpose of this paper, preservation relates to the presence of the species, but not to its age.

\section{MATERIALS AND METHODS MATERIJALI I METODE}

\section{Research area - Područje istraživanja}

The total surface of the island is 72 hectares. Due to its natural values, the island was put under protection already in 1949 as a Protected Natural Area, and in 1976 as a Special Forest Vegetation Reserve. The island belongs to Natura 2000 ecological network (HR40000017). Because of its valuable architectural heritage, the entire island was included to the list of UNESCO World Heritage Sites in 1979, together with the historical core of Dubrovnik. The ornamental gardens with the species planted in direct vicinity of the monastery, are subject to the provisions of the General Urban Development Plan of the City of Dubrovnik, i.e. they belong to the zone A - complete protection of historical structures (Official Gazette of the City of Dubrovnik 10/05, $10 / 07,8 / 12,03 / 14,07 / 16,09 / 17)$.

In terms of its climate, Lokrum is characterised by the climate typical for the coasts of the Mediterranean, subtype Csa according to Köppen (Šegota and Filipčić 2003). It features mild winter and hot, dry and sunny summer with precipitation in the driest summer month three times lower than in the rainiest month of winter. However, there are certain winter periods with stormy winds and heavy persistent rain and cold (temperature minimum for Dubrovnik is $-7.0^{\circ} \mathrm{C}$ ) (Makjanić and Volarić 1989).

In terms of vegetation and geography, Lokrum belongs to the Eumediteranneran area of evergreen forests and macchia of the order of Quercetalia ilicis Br.-Bl. (1931) 1936 (Ilijanić and Hećimović 1989). The natural forest stand of 


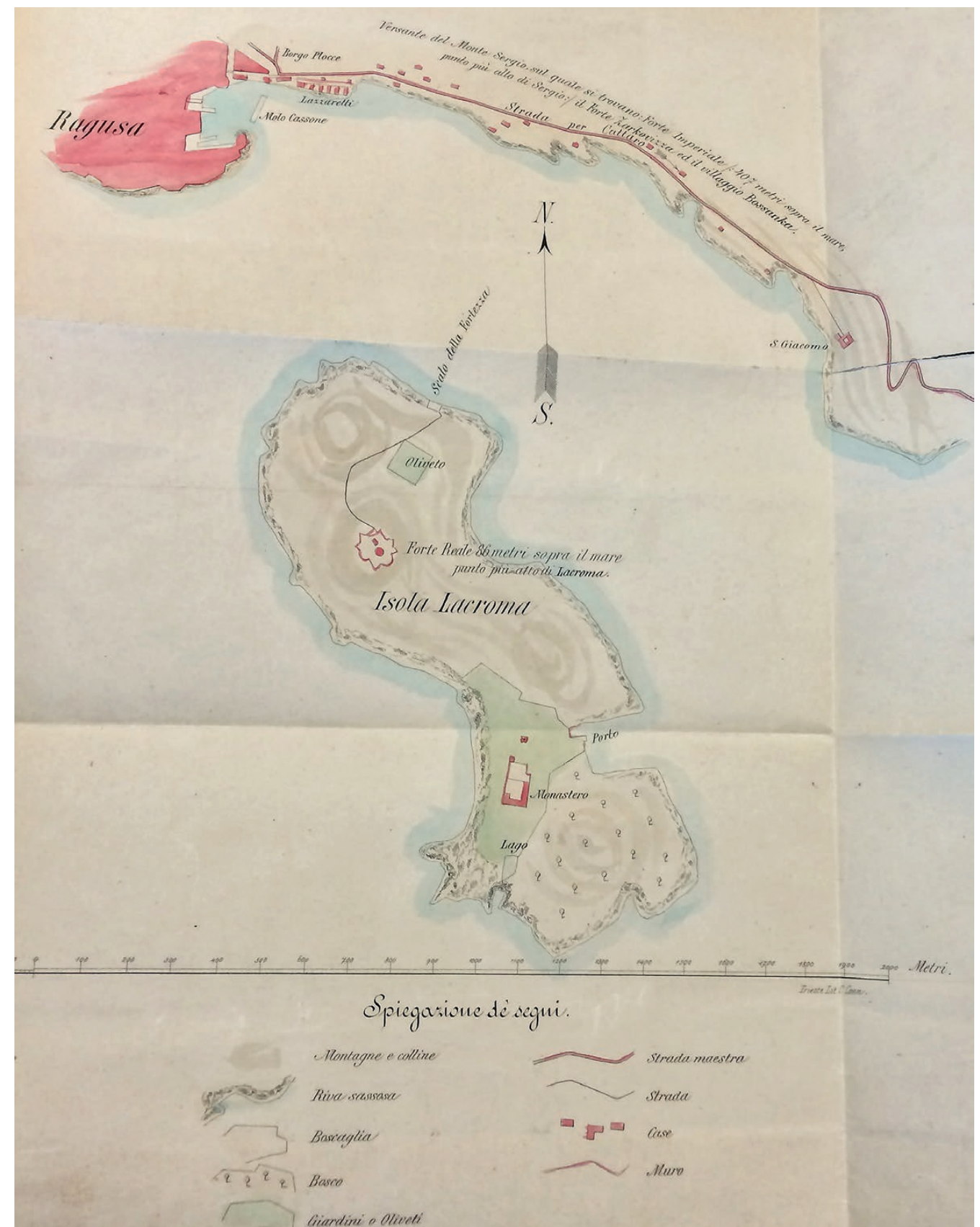

Figure 1. Layout of Lokrum gardens according to Roberto de Visiani, 1863 (source: Visiani, R., 1863: Sulla vegetazione e sul clima dell'isola di Lacroma in Dalmazia. Coen, Trieste).

Slika 1. Prikaz lokrumskih vrtova prema Robertu de Visianiu iz 1863. godine (izvor: Visiani, R., 1863: Sulla vegetazione e sul clima dell'isola di Lacroma in Dalmazia. Coen, Trieste).

the island is an evergreen forest of the holm oak and black ash as. Fraxino orni-Quercetum ilicis Horvatić (1956) 1958, largely developed in the form of lower and higher evergreen macchia in the north part of the island. The dominant species are Quercus ilex, Laurus nobilis, Viburnum tinus, Myrtus communis, Pistacia lentiscus, Arbutus unedo, Phillyrea latifolia, Lonicera implexa, Rhamnus alaternus, Erica arborea, Fraxinus ornus, etc. The south part of the island is mostly covered by planted forest of Aleppo pine (Pinus halepensis) growing on the base of macchia and pure macchia without the Aleppo pine. The majority of gardens that were subject to the introduction were located in the east part of the island, in front of the monastery, and towards the south in the wooded part of the island. Maximilian planted the exotics within the autochthonous vegetation which was supposed to protect these plants from the salt sediment and winds (De Visiani 1863). Taking into account very high winds, vicinity of the sea (salt sediment), but also the succession of the autochthonous vegetation of macchia, regardless of the intensive maintenance measures, the survival of the majority of introduced exotics was put into question. 


\section{Data sources - Izvori podataka}

In order to determine the list of the horticultural species planted on the island of Lokrum during Maximilian's reign (1859-1869), four archival sources were analysed (table 1); (a) invoices and reports of the court gardener Joseph Laube dating from the period of 1849-1863, listing 42 taxa (AST, N 30, f74, nn 4-370, 1859-60; N 31, f 75, nn 373-1233, 186162; AST, N 32, f 76, nn 1-69, 1863; N 33, f 77, nn 70-143, 1863; N 34, f 78, nn 144-237, 1863), (b) De Visiani's list of 90 taxa (De Visiani 1863), (c) list for the acquisition of plants made by the manager Junga in 1867, including 36 taxa (AST, N 48, f 95, 1857-67), (d) list of plants made as part of the island's value assessment conducted in 1873 and listing 73 taxa (AT-OeStA/HHStA PFF GDPFF SR 40-1). After Maximilian's death in 1867, the court in Vienna maintained the residence and gardens for two more years, until it was sold in June 1869 to a nobleman Dumičić. For the purpose of selling the island in 1873, a committee was set up to assess its value, which also included the parks (ATOeStA/HHStA PFF GDPFF SR 40-1). During the short period of the island being in his possession, Dumičić did not change the Lokrum parks, so this list of plants shows the allochthonous plants planted in the period of Maximilian. The common feature of these lists is the fact that they refer exclusively to the allochthonous and the autochthonous horticultural taxa.

On the basis of the mentioned sources and data collected in our own research, the following was analysed: number of individual taxa (species, subspecies, varieties, hybrids and cultivars), affiliation to genera, family, areal, number of autochthonous taxa, number of allochthonous taxa from different continents, and taxa introduced in Croatia for the first time. The status of invasive alien species (Inv - after the taxon name) was denoted according to Nikolić et al. (2014).

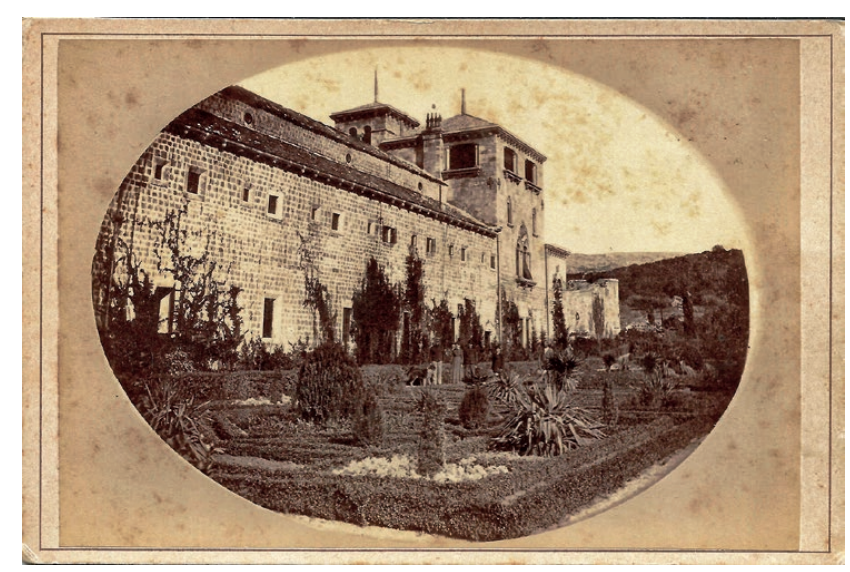

Figure 2. Photo of the ornamental gardens in front of the Maximilian's Residence, behind 1870, author Tomaso Burato (source: Dubrovnik Museums, Postcard Collection, F-3464).

Slika 2. Fotografija vrtova pred pročeljem Maksimilijanova zdanja, iza 1870 godine, autor Tomaso Burato (izvor: Dubrovački muzeji, Zbirka razglednica, F-3463)
The following groups of plants from Maximilian's period were analysed: deciduous trees, evergreen trees, shrubs, palm trees and succulents, herbaceous perennials, fruit trees and vegetable crops. In the end, the plants planted on Lokrum in the second half of the $19^{\text {th }}$ century were compared to our own recently conducted research and the lists of plants within the ornamental gardens immediately surrounding the monastery (own research 2018, 2019), while determining the percentage of the currently present plants planted in the time of Maximilian.

The taxa were identified according to Pignatti $(1982,1984)$, Tutin et al. (1964-1980, 1993) and Nikolić (2019a). The nomenclature of plants and families was harmonised according to The Plant List (http://www.theplantlist.org/), in accordance with the International Code of Nomenclature for Algae, Fungi and Plants (Turland et al. 2018). The names of authors of scientific names were standardised according to Brummit and Powell (1992). The names of cultivars were set out according to Hoffman (2016), in line with International Code of Nomenclature for Cultivated Plants (Brickell et al. 2016). Plant taxa listed in Table 1 were presented in the alphabetic order, while their segmentation as allochthonous or autochthonous taxa was organised according to the Flora Croatica Database (Nikolić, 2019b). The primary origin was presented according to Idžojtić (2013) and Idžojtić et al. (2019). The status of invasive plants (Inv) was marked according to Nikolić et al. (2014). The possible limitation of the research lies in the fact that some taxa have been wrongly identified at the time, but also in the fact that some taxa might not have been planted at all. A couple of species lacked their full taxonomic name, so this paper presents them only as their genera (e.g. Azalea sp.). The found archival lists of planted species do not include all of the autochthonous species, the typical representatives of the Lokrum macchia, which have also been planted at the time, according to the sources. Therefore, the comparison between the original archival lists and the conclusions relating to the present state refer exclusively to the horticultural and exotic species.

\section{RESULTS AND DISCUSSION REZULTATI I RASPRAVA}

Table 1 collectively presents the results of the plant inventory from Maximilian's period and the inventory of the present state. In total, the inventory listed 256 taxa, including 225 species, 1 subspecies, 3 varieties, 8 hybrids and 19 cultivars. The taxa belong to 179 different genera from $80 \mathrm{fa}$ milies. The total of 213 taxa were inventoried only from the period of Maximilian, including 184 species, 4 varieties, 8 hybrids and 17 cultivars (Table 1). The taxa belong to 149 different genera from 72 families. One bryophyte was recorded (Bryophytes) and 24 gymnosperms taxa (Gymnos- 
Table 1. List of horticultural allochthonous and autochthonous taxa of the ornamental gardens of Lokrum Island, planted in the period: gardener J. Laube 161 years ago (1859-1863), De Visiani 157 years ago (1863), Junga 153 years ago (1867), the present state of 1873 (147 years ago) and the current state plant inventarisation (own research 2018, 2019). Abbreviations and Symbols: Distribution: Afr $=A f r i c a, A z=A s i a, A u s=$ Australia, Eu = Europe, $\mathrm{Hr}=$ Croatia, $\mathrm{J} \mathrm{Am}=$ South America, Medit $=$ Mediterranean, NZ = New Zealand, Sj Am = North America, Sr Am $=$ Central America; križanac $=$ hybrid, kultivar $=$ cultivar. The presence of taxa: $\bullet=$ taxon present,$-=$ taxon not present.

Tablica 1. Popis hortikulturnih alohtonih i autohtonih svojti ornamentalnih vrtova otoka Lokruma sađenih u razdoblju: vrtlar J. Laube prije 161 godinu (18591863), De Visiani prije 157 godina (1863), Junga prije 153 godine (1867), popis procjene zatečenog stanja 1873. (prije 147 godina) i sadašnje stanje (vlastita istraživanja 2018, 2019). Kratice i simboli: Areal: Afr = Afrika, Az = Azija, Aus = Australija, Eu = Europa, J Am = Južna Amerika, Medit $=$ Mediteran, NZ = Novi Zeland, Sj Am = Sjeverna Amerika, Sr Am = Srednja Amerika. Prisutnost svojte: $\bullet=$ svojta prisutna, $-=$ svojta nije prisutna

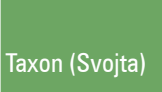

西

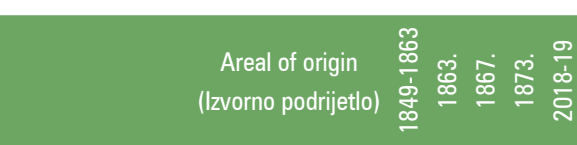

Abies pinsapo Boiss

Abutilon pictum (Gillies ex Hook.) Walp.

Acacia spectabilis Benth.

Acacia angustissima (Mill.) Kuntze

Acacia cyclops G.Don (= Acacia mirbe(iii Dehnh.)

Acacia dealbata Link

Acacia farnesiana (L.) Willd. (=

Mimosa farnesiana L.)

Acacia glauca (L.) Moench

Acacia myrtifolia (Sm.) Willd. (=

Acacia marginata R.Br.)

Acacia paradoxa DC.

Acacia robusta Burch.

Acacia subulata Bonpl.

Acacia trinervia Jacq.

Acaciella ferrisiae Britton \& Rose

Agathis australis (D.Don) Lindl. (=

Dammara australis D.Don)

Agave americana L.

Allium sp.

Allium sativum $\mathrm{L}$.

Aloe arborescens Mill.

Amaryllis sp.

Amelanchier ovalis Medik.

Ananas comosus (L.) Merr.

Anemone sp.

Araucaria araucana (Molina) K.Koch

Araucaria columnaris (G.Forst.) Hook.

Araucaria cunninghamii Mudie

Araucaria angustifolia (Bertol.) Kuntze

Araucaria bidwillii Hook.

Arbutus andrachne L.

Arbutus unedo L.

Aristolochia trilobata L.

Arundinaria sp.

Aspidistra elatior Blume

Astelia banksii A.Cunn.

Aucuba japonica Thunb.

Azalea sp.

Begonia $\times$ ricinifolia A.Dietr.

Bignonia sp.

Billbergia vittata Brongn. ex C.Morel

Bougainvillea spectabilis Willd.

Bouvardia ternifolia (Cav.) Schltdl.

Buxus sempervirens $\mathrm{L}$.

Caesalpinia gilliesii (Hook.) D.Dietr.

Callistemon hybridus DC.

Callistemon lanceolatus (Sm.) Sweet

Callistemon salignus (Sm.) Colv. ex Sweet

Callistemon viminalis (Sol. ex Gaertn.)

G.Don

Camellia japonica L.

Camphora officinalis Steud.

Campsis radicans (L.) Seem.

Canna indica $\mathrm{L}$.

Cassia sp.

Catharanthus roseus (L.) G.Don

Ceanothus sp.

Cedrus deodara (Roxb. ex D.Don) G.Don

Cedrus libani A.Rich.

Celtis australis L.

Ceratonia siliqua L.

Cereus alatus (Sw.) DC. (= Disocactus

alatus (Sw.) Kimnach)

Cestrum elegans (Brongn. ex Neumann)

Schltdl.

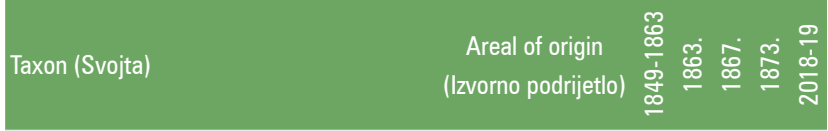

Chamaecrista desvauxii var. mollissima

(Benth.) H.S.Irwin \& Barneby

Chamaerops humilis $\mathrm{L}$.

Chorizema ilicifolium Labill.

Cinnamomum camphora (L.) J.Presl (=

Laurus camphora L.)

Cinnamomum verum J.Presl

Citrus reticulata 'Havana'

Citrus $\times$ aurantium $\mathrm{L}$.

Citrus limon (L.) Osbeck

Citrus medica $\mathrm{L}$.

Clerodendrum bungei Steud.

Clerodendrum chinense (Osbeck) Mabb

Cocculus laurifolius DC

Coleonema album (Thunb.) Bartl. \&

H.L.Wendl.

Colubrina macrocarpa (Cav.) G.Don

Convallaria majalis $\mathrm{L}$.

Cordyline fruticosa (L.) A.Chev.

Correa alba Andrews

Crassula perfoliata var. falcata

(J.C.Wendl.) Toelken

Crassula coccinea L.

Crataegus sp.

Crocus sp.

Cucumis melo $\mathrm{L}$.

Cucumis sativus $\mathrm{L}$.

Cuphea bustamanta Lex.

Cuphea micropetala Kunth

Cupressus sempervirens L. (=

C. sempervirens var. horizontalis (Mill.)

Loudon, $C$. sempervirens var. pyramidalis

(0.Targ.Tozz.) Nyman)

Cupressus funebris Endl.

Cupressus lusitanica Mill. (=

C. glauca Lam.)

Cupressus torulosa D.Don

Cycas revoluta Thunb.

Cydonia oblonga Mill.

Dracaena nutans Ridl.

Dracaena draco (L.) L.

Dracaena fontanesiana Schult. \& Schult.f.

Drepanostachyum falcatum (Nees) Keng $\mathrm{f}$.

(= Bambusa falcata (Nees) E.Vilm.)

Elaeagnus $\times$ reflexa E.Morren \& Decne.

Erica arborea L.

Eriobotrya japonica (Thunb.) Lindl.

Erythrina crista-galli L.

Eucalyptus globulus Labill.

Eucalyptus diversifolia Bonpl.

Euonymus japonicus Thunb.

Fabiana imbricata Ruiz \& Pav.

Fabronia ciliaris var. polycarpa (Hook.)

W.R. Buck

Fagopyrum esculentum Moench

Ficus carica L.

Ficus elastica Roxb. ex Hornem.

Ficus pumila L. (= Ficus stipulata Thunb.)

Fragaria $\times$ ananassa (Duchesne ex

Weston) Duchesne ex Rozier

Fraxinus ornus L.

Gardenia grandis 'Flore pleno'

Gardenia jasminoides J.Ellis

Geonoma maxima (Poit.) Kunth

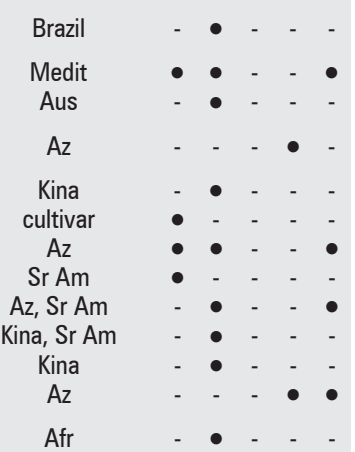

Kina, Sr Am

Kina, Sj Am

Kina, Sr Am

Aus

Afr

Afr

Eu

cultivar

$\mathrm{Az}, \mathrm{Am}, \mathrm{Afr}$

$A z, A m, A f r$

Sj Am, Sr Am, J

Am, Hawai

Mexico, Sr Am

Eu, Afr, Az

Kina

Mexico, $\mathrm{Sr} \mathrm{Am}$

$\mathrm{Az}$

Az

Az
Sr Am

Afr, Canary

Islands, Madeira

Cape Verde

Sr Am

Brazil

hybrid

Medit, Afr

$\mathrm{Az}$

Brazil

Aus

Aus

$\mathrm{Az}$

$\mathrm{J} A \mathrm{~m}$

Brazil

$\mathrm{Az}$

$\mathrm{Az}$
Kina, $\mathrm{Sr} A \mathrm{Am}$

$\mathrm{Az}$

hybrid

$\mathrm{Eu}, \mathrm{Az}$

cultivar

Kina, Sr Am

Brazil
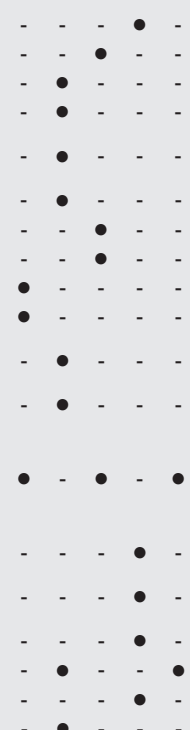

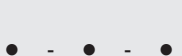




Taxon (Svojta)
Glandularia peruviana (L.) Small (=
Verbena chamaedryfolia Juss.)
Hedera helix L.
Hedychium coccineum Buch. Ham. ex Sm.
Heliocereus speciosus (Cav.) Britton \&
Rose
Heliotropium arborescens L.
Hibiscus syriacus L.
Hoya carnosa (L.f.) R.Br.
Hyacinthus sp.
Hydrangea macrophylla (Thunb.) Ser.
Hypericum calycinum L.
Ipomoea haylocki Regel
Jasminum officinale L.
Juglans regia L.
Justicia adhatoda L.
Justicia lancifolia (Nees) V.M. Badillo
Kunzea baxteri (Klotzsch) Schauer
Lantana camara L.
Lantana nivea Vent.
Lantana reticulata Pers.
Laurus nobilis L.
Ligustrum japonicum Thunb.
Linum grandiflorum Desf.
Magnolia grandiflora L.
Magnolia liliiflora Desr.
Malus domestica L.
Mammillaria sp.
Medicago sativa L.
Melaca busa

Melaleuca buseana (Guillaumin) Craven \& J.W.Dawson

Melaleuca hypericifolia Sm.

Melia azedarach L.

Mesembryanthemum sp

Metrosideros albiflora Sol. ex Gaertn.

Molineria capitulata (Lour.) Herb.

Morus alba L.

Morus sp.

Musa $\times$ paradisiaca L.

Musa acuminata Colla

Myrsine africana L.

Myrsine rotundifolia Lam.

Myrtus communis $\mathrm{L}$.

Myrtus communis subsp. tarentina (L.)

Nyman

Narcissus sp.

Nerium oleander $\mathrm{L}$.

Nicotiana glauca Graham (Inv)

Olea europaea 'Bjelica'

Olea europaea L.

Olea europaea 'Mrčakinja'

Olea europaea 'Murgulja'

Olea europaea 'Oblica'

Olea europaea 'Piculja'

Ophiopogon japonicus (Thunb.) Ker Gawl. Opuntia sp.

Opuntia ficus-indica (L.) Mill. (Inv)

Orchis sp.

Paeonia sp.

Panax quinquefolius $\mathrm{L}$.

Pandanus utilis Bory

Pandorea pandorana (Andrews) Steenis

Panicum miliaceum $\mathrm{L}$.

Parathesis crenulata (Vent.) Hook. f. ex

Hemsl.

Passiflora suberosa L.

Passiflora subpeltata Ortega

Paulownia tomentosa Steud.

Pelargonium $\times$ hortorum L.H.Bailey

Pelargonium inquinans (L.) L'Hér.

Pelargonium odoratissimum (L.) L'Hér.

Pelargonium peltatum (L.) L'Hér.

Pelargonium radula (Cav.) L'Hér.

Pelargonium zonale (L.) L'Hér. ex Aiton

Pentaclethra macroloba (Willd.) Kuntze (=

Acacia aspidioides G.Mey.)

Persea carolinensis (Raf.) Nees

Phillyrea latifolia L.

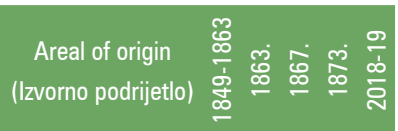

Brazil
Eu, Afr, Az
Kina
Mexico
Afr
Az
Kina, Sr Am
cultivar
Az
Eu, Az
Sr Am, J Am
Az
Az
Kina, Sr Am
Kina, Sr Am
Aus
Sr Am, J Am
Brazil
Sr Am
Medit
Japan
Sj Am
Sj Am
Kina
cultivar
Sr Am

Turkey, Rusia, Afr

Aus, New

Caledonia

Az, Aus

Brazil

Sj Am

$\mathrm{Az}$, Aus

$\mathrm{Az}$

$\mathrm{Az}$

hybrid

Sr Am

Afr

Medit

Medit

cultivar

$\mathrm{Eu}, \mathrm{Afr}, \mathrm{Az}$

$\mathrm{J} A \mathrm{~m}$

cultivar

Medit

cultivar

cultivar

cultivar

cultivar

Japan

$\mathrm{J} A \mathrm{~m}$

Mexico

cultivar

cultivar

Sj Am

Afr

Aus

$\mathrm{J}$ Am

$\mathrm{Sr} \mathrm{Am}$

Sr Am, J Am

$\mathrm{JAm}$

$\mathrm{Az}$

hybrid

Afr

Afr

Afr

Brazil

Eu, Afr, Az

Medit
Taxon (Svojta)

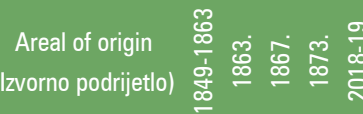

Phoenix dactylifera L.

Phoenix canariensis Chabaud

Phormium tenax J.R.Forst. \& G.Forst.

Photinia serratifolia (Desf.) Kalkman

Picea glauca (Moench) Voss

Pinus pinea $\mathrm{L}$.

Pinus sp.

Pinus halepensis Mill.

Pistacia lentiscus L.

Pittosporum tobira (Thunb.) W.T.Aiton

Platycladus orientalis (L.) Franco (=

Thuja orientalis L.)

Podocarpus elongatus (Aiton) L'Hér. ex Pers.

Polygala grandiflora Walter

Prunus armeniaca L.

Prunus domestica $\mathrm{L}$.

Prunus persica (L.) Batsch

Prunus dulcis (Mill.) D.A.Webb (=

Amygdalus communis L.)

Prunus laurocerasus $\mathrm{L}$.

Punica granatum $\mathrm{L}$.

Pyracantha crenulata var. crenulata

Pyrus communis L.

Quercus ilex L.

Quercus suber $\mathrm{L}$.

Ranunculus sp.

Rhamnus alaternus $\mathrm{L}$.

Rhapis excelsa (Thunb.) Henry

Ribes nigrum $\mathrm{L}$.

Ribes rubrum $\mathrm{L}$.

Ribes uva-crispa L.

Ricinus communis $\mathrm{L}$.

Robinia pseudoacacia L. (Inv)

Rosa banksiae 'Lutea'

Ruscus aculeatus $\mathrm{L}$.

Ruscus hypoglossum L.

Sabal minor (Jacq.) Pers.

Sabal palmetto (Walter) Lodd. ex Schult. \&

Schult.f.

Salvia $\times$ ianthina Otto \& A.Dietr.

Salvia confertiflora Pohl

Senna multiglandulosa (Jacq.) H.S.Irwin \&

Barneby

Sequoiadendron sp. (Wellingtonia sp.)

Serissa japonica (Thunb.) Thunb.

Solanum tuberosum $\mathrm{L}$.

Solanum atropurpureum Schrank

Solanum bonariense L.

Sorbus aucuparia L.

Spiraea $\times$ vanhouttei (Briot) Zabel

Strelitzia alba (L.f.) Skeels

Strelitzia reginae Banks

Syzygium australe (J.C.Wendl. ex Link) B.

Hyland

Taxus baccata $\mathrm{L}$.

Teramnus sp. (= Kennedya sp.)

Teucrium fruticans $\mathrm{L}$.

Thuja occidentalis $\mathrm{L}$.

Trachelospermum jasminoides (Lindl.)

Lem.

Trachycarpus fortunei (Hook.) H.Wendl.

Tristaniopsis laurina (Sm.) Peter G.Wilson

\& J.T.Waterh.

Tsuga canadensis (L.) Carrière

Tulipa sp.

Veronica speciosa R.Cunn. ex A.Cunn.

Viburnum tinus $\mathrm{L}$.

Vinca major $\mathrm{L}$

Vitis vinifera 'Boal'

Vitis vinifera 'Malvasia'

Washingtonia robusta H.Wendl.

Westringia fruticosa (Willd.) Druce

Wigandia urens (Ruiz \& Pav.) Kunth

Yucca filamentosa $\mathrm{L}$.

Yucca gloriosa var. tristis Carrière

Yucca gloriosa $\mathrm{L}$.

Zamia pumila $\mathrm{L}$.

Zea mays L.

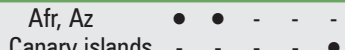

Afr, Canary islands - $-{ }_{-}$

Aus

$\mathrm{Az}$

Sj Am

Eu, Afr, Az

Medit

Medit

$\mathrm{Az}$

$A z$

Afr

Cosmopolitan

$\mathrm{Az}$

$A z$

$\mathrm{Eu}, \mathrm{A}$

$\mathrm{Eu}, \mathrm{Az}$

Kina, Nepal

$\mathrm{Eu}, \mathrm{Az}$

Medit

Medit

cultivar

Medit

Kina

Eu

Eu, Sj Am

Afr

Sj Am

cultivar

Eu, Afr, Az

Sj Am, Mexico

Sj Am

hybrid

Brazil

Sr Am, J Am

Sj Am

Kina, Japan

Sj Am, J Am

$\mathrm{J} A \mathrm{~m}$

$\mathrm{J} \mathrm{Am}$

Eu

hybrid

Afr

Aus

Eu, Afr, Az

$\mathrm{J} A \mathrm{~m}$

Medit

Sj Am

Az

$\mathrm{Az}$

Aus

Sj Am

cultivar

NZ

Medit

Eu, Az

cultivar

cultivar

Sj Am

Aus

Sr Am

Sj Am

Sj Am

Sj Am

$A z$

Sr Am (Mexico) 
perms). Other 188 taxa (88.3\%) are angiosperms; 157 of them are dicotyledons (Dicotyledones) and 31 are monocotyledons (Monocotyledones). All taxa, with the exception of 5 vegetable species and 3 species of grains, belong to woody perennials or herbaceous perennials. For the territory of Croatia, only 20 (9.5\%) autochthonous taxa were recorded, the majority of which were Mediterranean and European species. The most of the exotic taxa, i.e. the ones that grow exclusively outside of the European continent, came from North, Central and South America, including the individual countries of Brasil and Mexico (79; $37.1 \%)$. These were followed by Asian taxa, including China and Japan (47; $22.1 \%)$, and Australian taxa $(21 ; 9.9 \%)$ and areal taxa from Africa (17; 8.0 \%). The rest of the taxa are native and/ or thrive on several continents, e.g. in Europe, Africa and Asia. The most represented genera are: Acacia (11), Pelargonium (6), Olea (5) and Araucaria (5 taxa). The most represented families are Leguminosae (21), Rosaceae (17), Myrtaceae (12), Asparagaceae (8), Pinaceae (8), Oleaceae (7) and Cupressaceae (7 taxa).

Judging by the groups of plants from Maximilian's period, the most of them were perennials (50; $23.5 \%)$, followed by deciduous (26) and coniferous trees (22, in total $48 ; 22.5$ $\%)$, shrubs (44; $20.7 \%$ ), fruit trees and grapevines (28; 13.2 $\%)$, palm trees and succulents (19; $8.9 \%)$, climbers (8) and cultivated herbaceous perennials (bulbs) also 8 (3.8 \%), vegetable and forage crops $(5 ; 2.4 \%)$ and grains $(3 ; 1.4 \%)$.

According to 2018-2019 inventory, 71 taxa were inventoried within the Lokrum ornamental gardens today, belonging to 43 families and 64 genera. There were 5 gymnosperms (Gymnosperms) recorded, and 66 angiosperms; 51 dicotyledons (Dicotyledones) and 16 monocotyledons (Monocotyledones). The most represented families were: Asparagaceae (8), Rosaceae (5), Arecaceae (4) and Oleaceae (4), while the most represented families from the $19^{\text {th }}$ century (Leguminosae, Rosaceae and Myrtaceae) were reduced to the minimum. The genera were largely represented with only one taxon, while the most represented genera are that of Yucca with 3 taxa. There are 3 invasive species present on the island today (Nikolić et al. 2014): Nicotiana glauca, Robinia pseudoacacia and Opuntia ficus-indica, which was, according to the photographs, planted already in the period of Maximilian. Out of 71 recorded taxa, 51 (71.8\%) are allochthonous, mostly woody plants, while there are 20 autochthonous taxa, that largely include woody macchia and autochthonous woody fruit trees. In comparison with the list made at the time of Maximilian, 41 of today's taxa were not recorded. Subsequently, only 30 taxa (14.1\%) from that period remained present, mostly originating from Asia (17 taxa: Asia, including China and Japan) and 9 Mediterranean taxa, mostly autochthonous species and occasionally 4 other species originating from other parts of the world. Therefore, one must take into account that many autocht- honous species of Mediterranean macchia that were present in Maximilian's period within his ornamental gardens, and some of them were planted according to the design, especially in front of the residence, were not fully recorded in the plant inventories in the archival sources. Namely, the archival sources show that a nursery has been constructed in order to cultivate different autochthonous plants, and they explicitly mention Arbutus unedo and Pinus halepensis (AST, N 34, f 78, nn 144-237, 1863).

There were 9 Mediterranean, largely autochthonous taxa determined, and 6 naturalised in our climate, which were also present in Maximilian's period: Arbutus unedo, Buxus sempervirens, Citrus x aurantium, Citrus medica, Ficus carica, Laurus nobilis, Myrtus communis, Olea eruopea, Prunus persica, Rhamnus alaternus, Viburnum tinus, Chamaerops humilis, Cupressus sempervirens, Pinus halepensis and Ceratonia siliqua. Autochthonous varieties of olives from $\mathrm{Du}$ brovnik area were planted: Olea europaea 'Bjelica', Olea europaea 'Mrčakinja,', Olea europaea 'Murgulja', Olea europaea 'Oblica', Olea europaea 'Piculja' (Marinović-Peričević and Družić 2004). Only 20 taxa of horticultural exotic (allochthonous) species planted in that period, which were at that time considered exotics, have remained. These are largely taxa originating from Asia (15 taxa: Asia, including China and Japan) belonging to woody or herbaceous perennials, which were able to thrive in the south of Dalmatia due to similar climate. Maximilian's gardens are today managed by professional services of the Lokrum Reserve, in terms of regular pruning and disease and pest control. Considering the existing fund of the plants in the gardens, where the allochthonous species became domesticated over time, their future survival is not in question.

A special feature of Maximilian's undertaking lies in the fact that he, as a supreme commander of the Austrian navy, has personally organised and took part in research expeditions aimed at collecting seeds of various exotic species from different parts of the world (Riedl-Dorn 1992, 2012). A big two-year research expedition around the world on a steamboat Novara (1857-59) has been the biggest and the most ambitious Austrian expedition at the time, during which 26,000 exhibits, i.e. 3,000 plant species were collected, partly as seeds, partly in herbarium collections. During the preparations for the two-year expedition around the world onboard Novara, Maximilian's advisor was the famous Alexander von Humboldt (Scherzer 1861). The second expedition was the so-called Brazilian expedition (1859-60), in which Maximilian personally took part. One of its results was a list and a systematisation of the found plants from the family of Araceae, due to which the entire collection, as well as some newly found plants were named after Maximilian Aroidae Maximilianae (Peyritsch and Schott 1879). There is an interesting historical fact saying that both of these big research expeditions had their ceremonial closings in $\mathrm{Du}-$ 
brovnik (Scherzer 1861, Wawra 1866). After the end of the Brazilian expedition, the seeds and tubers of the plants were taken in crates from the Fantasie ship to the Island of Lokrum (AST, N 30, f 74, nn 4-370, 1859-60). Apart from the distant destinations visited during the expeditions, a large part of the exotic plants that were until then already domesticated in Europe, came to Lokrum from different European destinations; Padua, Schönbrunn, Leipzig, Zagreb, London, Venice, Trieste, Graz, Vis, Korčula, Meljine, Corfu, Malaga, Madeira, Gibraltar (AST, N 30, f 74, nn 4-370, 1859-60). Maximilian's personal passion for botany and beautiful gardens, was also encouraged by Romanticist trends in the $19^{\text {th }}$ century horticulture, which were largely characterised by the introduction of exotic plants and made possible due to trade and traffic throughout the world (Hajós 2004), and which represented a symbol of luxury and power of their owners (Carder 1986). Maximilian has had greenhouses put up in both locations, Miramar residence and Lokrum island, for the propagation of the introduced plants, which enabled the production and collecting of exotics.

In establishing the floristic specialty of Lokrum and the exclusivity concerning the introduction, the island was compared to other well-known parks on the east Adriatic coast, which are spatially and temporally similar and which also featured the introduction of plants that were exotic at the time. This would primarily be Maximilian's park Miramar beneath Grignano in Trieste, where a forestry and horticultural experiment was carried out: a bare rocky spur of limestone origin was afforested, and the exotics tried to be introduced (Moser 1903, Chersicla 2000). The second point of reference is the Garagnin Park in Divulje near Trogir, which in its type was a ferme ornée or a so-called "ornamental farm" (Šverko 2009), on the basis of which Maximilian analysed the way in which the autochthonous plants could be skilfully combined with the then new and exotic plants, but also with agricultural crops (Bužančić 1995, Biasoletto 1841). The third point is Gučetićs Park in Trsteno, which was visited by Maximilian and his associates De Visiani and doctor Jilek (AST, N 34, f 78, nn 144-237, 1863).

While analysing the lists of plants from these four parks created in the second part of the $19^{\text {th }}$ century, it may be determined without a doubt that some species and varieties of plants introduced and cultivated on Lokrum were introduced in this part of the Adriatic for the first time. The most popular items on this list are the pineapple (Ananas comosus (L.) Merr.) and two types of banana (Musa x paradisiaca L., M. acuminata Colla), which were mentioned by De Visiani (1863), who said that they have survived on the island "for two years without protection". The species of Musa ensete J.F. Gmeli and M. cavendishii Lamb (Moser 1903) were introduced in Maximilian's Miramar park. In 1863, M. ensete was present in Gozze park. The owners of more luxurious patrician parks in Dubrovnik area started grow- ing bananas on the turn of the twentieth century (Marić and Šćitaroci 2015). There were two species of eucalyptus recorded on the Island of Lokrum in Maximilian's time, Eucalyptus diversifolia Bonpl. (De Visiani 1863) and E. globulus Labill. (AST, N 48, f 95, 1857-67). The first introduction of eucalyptus E. globulus Labill. in a public area took place in 1854 in France (Le Floc'h 1991). The same species was recorded in a nursery in Pula in 1874 (Antoine 1874, Wawra 1875). In Trsteno, E. globulus Labill. was recorded in 1881 (Kovačević 2012). All this leads to a conclusion that the first introduction of eucalyptus in this part of Adriatic took place on Lokrum. Another specialty of Lokrum is the collection of five different species of Araucaria from Maximilian's period; Araucaria araucana, A. columnaris, A. angustifolia, A. bidwillii and A. cunninghamii. At that time, two species of Araucaria were thriving in Miramar; A. columnaris and A. araucana (Moser 1903). In Trsteno, a specimen of A. araucana was recorded in 1889 (Kovačević 2012). Bougainvillea spectabilis was for the first time cultivated in Europe in 1829 (Wawra and Abel 1886), although it was discovered in late $18^{\text {th }}$ century in South America (Lack 2012, Roy et al. 2016). This attractive climber was cultivated in mid-19 $9^{\text {th }}$ century in greenhouses of imperial palaces and botanical gardens, and in late $19^{\text {th }}$ century in outdoor gardens (Sauvaigo 1894). At that time, we could not even find it on the lists of plants planted in Garagnin park or in Trsteno. It was recorded on Lokrum by De Visiani (1863), which proves that Lokrum has been the location of its first cultivation in this part of Adriatic in a park area. Different cultivars of Bougainvillea were intensively cultivated in Dubrovnik area in the $20^{\text {th }}$ century and over time they became the one of the most recognisable floral elements of gardens in Dubrovnik (Šišić 2003b). In a letter written in 1863, sent from Corfu, the main topic was the acquisition of citrus fruits (AST, N 34, f 78, nn 144-237, 1863), where among 62 seedlings, there were 12 mandarin seedlings, which were stated to be very hard to acquire, and they were acquired according to Maximilian personal wish. Unlike oranges, lemons and citrons, mandarins were cultivated relatively late in Dubrovnik area, not before the late $19^{\text {th }}$ and early $20^{\text {th }}$ century (Kaleb 2014). The first mandarin variety cultivated in the Mediterranean is the variety of Citrus reticulata 'Havana', so-called Mediterranean mandarin (Langgut 2017). This variety had been imported to England from China, and it was recorded in 1805 in the Kew Royal Botanical Garden, from where it has spread to the English colony of Malta, and further on to Italy and the Mediterranean. They cannot be found in the published plant inventories of the parks Miramar, Garagnin and Trsteno made in the second half of the $19^{\text {th }}$ century. Only in 1911 Adamović (1911) mentioned there were mandarins in the park in Trsteno. Therefore, we might say that the first mandarins in Dubrovnik area were imported right into Maximilian's 
park on the Island of Lokrum. It is an interesting fact that at the time of Maximilian, there was an entire collection of acacias / sensitive plants on Lokrum, as much as 11 species (Table 1). This is the genera easily cultivated in favourable climate such as the one on Lokrum. In its memoirs, Maximilian mentioned that they have collected seeds of different species of acacias on the Island of St. Vincent in the Caribbean (Maximilian 1868). On Lokrum, Maximilian intended to establish an outdoor acclimatisation garden for the then exotic, mostly tropical plants, within the natural autochthonous vegetation of the island. And during his time on the island, he succeeded in that (De Visiani 1863, Portilla 1864). Such concept of planted exotics was preserved until 1873 , when the evaluation of the special exotic fund of the park determined the departed plant specimens in excellent state (AT-OeStA/HHStA PFF GDPFF SR 40-1). During the time of Maximilian, there was one head gardener and one assistant gardener employed on the island, including 7-20 local workers, who were engaged on the works in the garden on daily basis. The concept of planting the allochthonous plants within the natural island vegetation required daily care, especially in terms of weed protection, but also irrigation and constructing wind protection structures, as recorded by the court head gardener J. Laube (AST, N 30, f 74, nn 4-370, 1859-60). After Maximilian's period, garden maintenance was never again at the same level. What followed was a successive degradation until the present days.

The analysis of the taxa inventories from the second half of the $19^{\text {th }}$ century shows that there were 213 taxa in total. Compared to the present state (Table 1), there is a notable difference in the taxa in the ornamental gardens, especially the allochthonous ones, which were then considered exotic. Out of 51 ornamental allochthonous taxa identified today, which is a quarter of the number from the time of Maximilian, only 21 taxa were preserved from his period, such as; Aucuba japonica, Bougainvillea spectabilis, Canna indica, Chamaerops humilis, Cedrus deodara, Cocculus laurifolius, Cycas revoluta, Eriobotrya japonica, Ligustrum japonicum, Pittosporum tobira, Strelitzia reginae, Taxus baccata and Yucca gloriosa. Among them, the specimen of Cycas revoluta and Taxus baccata, located in the gardens in the west part of the compound, represent the oldest original allochthonous taxa from the mid- $19^{\text {th }}$ century. It was determined that today there are 20 autochthonous taxa ( 9 of them persisted from the time of Maximilian) within the area of the ornamental gardens. Due to lack of intensive maintenance within the autochthonous island vegetation, the majority of the allochthonous exotic taxa failed to survive. The most numerous planted woody taxa from the time of Maximilian is Cupressus sempervirens (own research 2018, 2019). These cypresses were planted along the walkways in the north part of the island, as well as in the direct vicinity and in front of the Benedictine monastery and Maximilian's mansion. An interesting fact says that until the end of 1863, Maximillian has had over 700 cypress seedlings planted (AST, N 30, f74, nn 4-370, 1859-60; AST, N 31, f 75, nn 373-1233, 1861-62; AST, N 32, f 76, nn 1-69, 1863). This has been confirmed with the recent research establishing that the most numerous planted units on the island are Cupressus sempervirens 'Pyramidalis' and C. sempervirens 'Horizontalis' (Hudina et al. 2019). The specimen of Buxus sempervirens, located within the gothic-renaissance cloister of the Benedictine monastery, are among the oldest autochthonous taxa from the second part of $19^{\text {th }}$ century.

The purpose of this research was to carry out a comprehensive review of the horticultural taxa planted in the second half of the $19^{\text {th }}$ century. The identified list is important in the context of the restauration works that awaits Maximilian's gardens on Lokrum. Thereby, the possible reintroduction of the certain taxa must be considered in light of the several facts. The island of Lokrum is today fully protected as a Special Forest Vegetation Reserve, which includes the area of the ornamental gardens originating from the times of Maximilian. Therefore, the possible reintroduction of the certain taxa should be in line with the ecological, phytosociological and landscape features of the Lokrum area.

It is a very important fact that in 1959 , a botanical garden was established on Lokrum, covering the surface of 2 hectares. This was done precisely in order to research the adaptation to the Lokrum climate of taxa originating from the tropical or subtropical areas (Dolina and Jasprica 2011), which are located outside of the areal of the ornamental gardens covered by this paper. In this context, Maximilian's garden in a certain way lost one of their main original functions. Still, their value is undeniable in light of their historical, stylistic and symbolic significance and due to the fact that an archduke, who later became an emperor, was personally involved in their creation. For all of the mentioned reasons, when renovating the gardens, one should not consider the introduction of all taxa from the original list, but select the taxa that significantly contribute to renewal of the stylistic features of these gardens at the time of their original creation. At the same time, all invasive and potentially invasive taxa that are not included in the official lists of invasive plants, such as the taxa from the genera of Pittosporum, Mesenbriamthemum, Acacia etc., should be excluded. A substantial influence on the selection of taxa should come from sustainability and maintenance of the gardens, since the "life" of a garden begins only after these have been ensured.

\section{CONCLUSIONS}

\section{ZAKLJUČCI}

This research was the first one to determine the quantity of the horticultural taxa planted on Lokrum in the second half of the $19^{\text {th }}$ century when the island had been the property 
of the archduke Maximilian von Habsburg, by using the archival sources from Trieste State Archives (AST) and Austrian State Archives (OeStA) in Vienna. The botanical analysis determined the number of species, subspecies, varieties, hybrids and cultivars, including affiliation to family, areal, and share of autochthonous taxa from the certain continents in the second half of the $19^{\text {th }}$ century, as well as the taxa that were recently present in the ornamental gardens. The analysis also determined the today's number of the allochthonous taxa, continuously present since the second half of the $19^{\text {th }}$ century. Finally, the analysis identified those taxa that are unique or rarely present in Croatia, and that were planted on Lokrum for the first time.

The research identified a relatively large variety of the horticultural species from the period of the second half of the $19^{\text {th }}$ century. Very small number of these taxa (30) remained preserved until today. The reason for this mostly relates to a discontinuity in the garden maintenance. The value of this research lies in positioning the horticultural significance of Maximilian's gardens on Lokrum, relative to other similar gardens of the same period, such as the Maximilian's park at the Miramar castle, Garagnin park in Trogir and Trsteno park from the same period. This research is an important starting point for reviewing the fund of the horticultural species, which will be a part of the concept of restoration of Maximilian's gardens on Lokrum.

\section{REFERENCES}

\section{LITERATURA}

- Adamović, L., 1911: Dier Pflanzenwelt Dalmatiens. Verlag von dr Werner Klinkhardt, Leipzig, 98 pp.

- Antoine, F., 1874: Über Eucalypti Anpflanzungen. Österreichische botanische Zeitschrift, 24(10): 309-310.

- Arnold, Z., 1938: Slike iz vrtova Dalmacije, Parkovi na Lokrumu i Lopudu. Naš vrt, revija za kulturu vrta i za sveukupno vrtlarstvo 5(3-4): 49-55.

- Biasoletto, B., 1841: Relazione del viaggio fatto nella primavera dell'anno 1838 dalla maestà del re Federico Augusto di Sassonia nell'Istria, Dalmazia e Montenegro. Tipografia Weis, Trieste.

- Božić-Bužančić, D., 1995: Južna Hrvatska u europskom fiziokratskom pokretu. Pokret za obnovu gospodarstva, gospodarske akademije, ogledni vrtovi i poljodjelske škole druge polovice XVIII. i početka XIX. st.. Književni krug u Splitu, Biblioteka znanstvenih djela 76., Split, pp 245.

- Brickell, C. (ur.), 2003: RHS A-Z encyclopedia of garden plants. Vol. I-II. Dorling Kindersley, London.

- Brummitt, R. K., C. E. Powell, 1992: Authors of plant names. Royal Botanic Gardens, Kew, pp 732.

- Carder, J., 1986: Formalism in the Victorian garden. Sheffield Hallam University, Sheffield, pp 22-40.

- Du Cange, C., 1883: Glossarium mediæ et infimæ latinitatis. L. Favre, Imprimeur-Éditeur, Niort, pp 62.

- Chersicla, B., 2000: Nel parco di Miramare dodici alberi esotici. Edizioni Bassanese, Trieste.
- De Diversis, F., 2007: Opis slavnog Grada Dubrovnika. Sabrana djela, Zagreb, 68 pp.

- Dolina, K., Jasprica, N., 2011: Povijest, ciljevi i budućnost Botaničkog vrta na Lokrumu. U: S. Kovačić, V. Stamenković (ed.), Sekcija botaničkih vrtova i arboretuma Hrvatskog botaničkog društva, pp 31-32.

- Dorsi, P., 1986: La nascita del Parco di Miramare nelle Relazioni inedite di Anton Jelinek. Un giardino in riva al mare Il parco di Miramare ieri e domani: vicende storiche e prospettive culturali. Edizioni Dedolibri, Trieste, 21-54 pp.

- Đurasović, P., 1997: Unošenje egzotičnog drveća i grmlja na dubrovačko područje. Šumarski list 121 (5-6): 277-289.

- Hajós, G., 2004: Perivojni gradski prostori u eruopskim zemljama i u Beču. u: Gradski perivoji Hrvatske, ed. B. Bojanić Obad Šćitaroci i M. Obad Šćitaroci, Šćitaroci d.o.o., Arhitektonski fakutlet, Zagreb, pp 12-34.

- Hirc, D., 1905: Prirodni zemljopis Hrvatske. Knjiga prva: Lice naše domovine. Antun Scholz, Zagreb, pp 661.

- Hoffman, M. H. A., 2016: List of names of woody plants. International standard ENA 2016 - 2020. Naktuinbouw, Roelofarendsveen, pp 1080.

- Horvatić, S., 1859: Karta realne vegetacije otoka Lokruma u mjerilu 1:20.000, Sveučilište u Dubrovniku, Institut za more i priobalje.

- Hudina, T., Budinski I., Katanović I., 2019: Katastar kultiviranih biljaka otoka Lokruma. U: M. Crnčević, A. Bratoš Cetinić (ed.), Otok Lokrum znanstveno-stručni skup s međunarodnim sudjelovanjem. Javna ustanova Rezervat Lokrum, Dubrovnik, pp 94.

- Generalni urbanistički plana grada Dubrovnika. Službeni glasnik Grada Dubrovnika 10/05, 10/07, 8/12, 03/14, 07/16, 09/17.

- Ilijanić, Lj., Hećimović, S., 1989: Vegetacijske i biljnogeografske značajke dubrovačkog područja s posebnim obzirom na otok Lokrum. U: M. Meštrov, M. Kerovac M. (ed.), Otok Lokrum, Sveučilište u Zagrebu, Hrvatsko ekološko društvo, Zagreb, pp 139-163.

- Idžojtić, M., 2013: Dendrologija: cvijet, češer, plod, sjeme. Sveučilište u Zagrebu Šumarski fakultet, 672 pp.

- Idžojtić, M., Anić, I., Šimić, I., Kovačević, M. A., Poljak, I., 2019: Dendrološke značajke arboretuma Trsteno, Šumarski list 143 (3-4): 125-143.

- Kaleb, M., 2014: Razvoj uzgoja mandarina i ostalih agruma u dolini Neretve. Agronomski glasnik 76(4-5): 219-238.

- Kapović, N., 2002: Vrtovi u sklopu Maksimilijanova ljetnikovca na otoku Lokrumu. Agronomski glasnik 64(1-2): 87-109.

- Kovačević, M., 1978: Pregled razvoja obogaćivanja hortikulturne flore Sredozemlja kao prijedlog obnavljanja botaničke komponente pet st. starog perivoja Gučetića, Rad JAZU, Knjiga 379, Razred za likovne umjetnosti VII: 231-237.

- Kovačević, M., 2012: Perivoj Gučetićeva ljetnikovca u Trstenom - od renensansnog perivoja do arboretuma; preobrazbe autohtonog renesansnog predloška i njegov utjecaj na ladanjske perivoje dubrovačkog područja. Disertacija, Sveučilište u Zagrebu Arhitektonski fakultet, Zagreb, pp 151-152.

- Lack, H. W., 2012: The discovery, naming and typification of Bougainvillea spectabilis (Nyctaginaceae). Willdenowia 42(1): 117-126.

- Le Floc'h, E., 1991: Invasive plants of the Mediterranean Basin. U: R. Groves, F. Di Castri (Eds.), Biogeography of Mediterra- 
nean Invasions, Cambridge University Press. Cambridge, pp 67-80.

- Langgut, D., 2017: The Citrus Route Revealed: From Southeast Asia into the Mediterranean. HortScience 52(6): 814-822.

- Lorenzo, P., González, L., Reigosa J.M., 2010: The genus Acacia as invader: the characteristic case of Acacia dealbata Link in Europe. Ann. For. Sci. 67 (1):101-111.

- Makjanić, B., Volarić, B., 1989: Neke osobine klime Lokruma i šire okolice. U: M. Meštrov (ed.), Otok Lokrum, Hrvatsko ekološko društvo, Zagreb, pp 27-52.

- Marić, M., Obad Šćitaroci M., 2015: Perivoj ljetnikovaca BonaCaboga i Stay-Caboga u Dubrovniku. Razvoj i mijene. Prostor, 23:1(49), 2-13.

- Marić, M., Đukanović, N., Viđen, I., 2018: Vrtna studija za Benediktinski samostan i Maksimilijanov ljetnikovac na otoku Lokrumu. Studija, Sveučilište u Dubrovniku, Dubrovnik.

- Marić, M., Marinović-Peričević, M., Medović, M., 2019: Vrtna studija pristupnih šetnica Benediktinskog samostana i Maksimilijanovog ljetnikovca na otoku Lokrumu. Studija, Sveučilište u Dubrovniku, Dubrovnik.

- Marinović-Peričević, M., Družić, J., 2004: Rezervat Lokrum. Obnova starog maslinika na otoku Lokrumu. Studija, Zavod za mediteranske kulture Sveučilišta u Dubrovniku, Dubrovnik.

- Maximilian I, Emperor of Mexico, 1868: Recollections of My Life. vol. 3., Richard Bentley, London, pp 75.

- Moser, K., 1903: Verzeichnis der Pflanzenarten des k.u.k. Hofgartens von Miramar, mit eniem vortworte und einer einleitung. Buchbruderei des osterr., Trieste, pp 13.

- Nikolić T., 2019a: Flora Croatica 4 - Vaskularna flora Republike Hrvatske. Alfa d.d., Zagreb.

- Nikolić T., 2019b: Flora Croatica Database. University of Zagreb, Faculty of Science, Department of Botany http://hirc.botanic.hr/ fcd (accessed: January 08, 2020)

- Nikolić T., B. Mitić, I. Boršić, 2014: Flora hrvatske: invazivne biljke (Flora of Croatia: Invasive Plants). Alfa d.d., Zagreb.

- Peyritsch, J., Schott, H.W., 1879: Aroideae Maximilianae: die auf der Reise Sr. Majestät des Kaisers Maximilian I. nach Brasilien gesammelten Arongewächse. Druck und Verlag von C. Gerold's Sohn, Wien.

- Pignatti, S., 1982, 1984: Flora d'Italia I-III. Edagricole, Bologna.

- Portilla, A., 1864: De Miramar a Mexico, Viaje de Emperador Maksimilijano y de la Emperatriz Carlota, Desde su Palacio de Miramar cerca de Trieste hasta la Capital del Imperio Mexicano. Imprenta de J. Bernardo Aburto, Orizaba, pp 44.

- Razzi, S., 2011: Povijest Dubrovnika. transl. I. Grgić. S., Krasić S., Matica hrvatska, Ogranak Dubrovnik, Dubrovnik, pp 191192.

- Riedl-Dorn, C., 1992: Zur Naturkundlichen Entdeckung Amerikas: Blumen eines Kaisers- Maximilian von Mexiko und seine Brasilienexpedition 1859-1860 - Kataloge des OÖ. Landesmuseums N.F. - 0061, Linz, pp 3-153.

- Riedl-Dorn, C., 2012: Botaniker oder Pflanzensammler? Die Rolle der Pflanzenkunde bei der Weltumseglung der Fregatte „Novara“ (1857-1859). Verhandlungen der Zoologisch-Botanischen Gesellschaft in Österreich Bd. 148/149, Wien, pp 363376.

- Roy, R., K., Sing, S., 2016: Migration and domestication of Bougainvillea: a historical review. Chronica Horticulture 56(2): 9-14.
- Sauvaigo E., 1894: Les cultures sur le littoral de la Méditerranée: Provence, Ligurie, Algérie.JrB. Baillière et Fils, Paris.

- Skok, P., 1950: Slavenstvo i romanstvo na jadranskim otocima, Toponomastička ispitivanja. Filozofski fakultet Sveučilišta u Zagrebu, Zagreb, pp 247.

- Scherzer K., 1861: Narrative of the circumnavigation of the globe by the Austrian frigate Novara (Commodore B. Von Wullerstorfurbair), Undertaken by order of the Imperial Government in the years 1857, 1858, 1859, under the immediate auspices of his I. and R. Highness the Archduke Ferdinand Maximilian, Commander - in - Chief of the Austrian Navy. Volumen III., Saunders, Otley, and co., London, pp 458.

- Statut grada Dubrovnika, 1272: Priredili i na hrvatski jezik preveli A. Šoljić, Z. Šundrica, I. Veselić; uvodnu studiju napisala N. Lonza. 2002. Državni arhiv u Dubrovniku, Dubrovnik 2002, pp 105-106.

- Šegota, T., Filipčić, A., 2003: Köppenova podjela klima i hrvatsko nazivlje. Geoadria 8(1):17-37.

- Šišić, B., 1968: Prilog raspravama u uređenju i korištenju otoka Lokruma. Hortikultura 35(1-2): 31-32.

- Šišić, B., 1989a: Otok Lokrum, Izuzetan perivoj u gradskom prostoru Dubrovnika. U: M. Meštrov (ed.), Otok Lokrum, Hrvatsko ekološko društvo, Zagreb, pp 165-182.

- Šišić, B., 1989b: Idejno rješenje pejzažnog i vrtnog uređenja Lokruma. Provedbeni urbanistički plan Lokrum. Prostorni plan, Državni arhiv u Dubrovniku, Opus Bruna Šišića, kutija 89, Dubrovnik.

- Šišić, B., 2001: Vrtovi benediktinske opatije na otoku Lokrumu. Anali zavoda za povijesne znanosti HAZU u Dubrovniku 39 (1):397-426.

- Šišić, B., 2003a: The Gardens of the Benedictine Abbey on the Island of Lokrum. Dubrovnik Annals 7 (1): 99-122.

- Šišić, B., 2003b: Vrtni prostori povijesnog predgrađa Dubrovnika. Od Pila do Boninova. Hrvatska akademija znanosti i umjetnosti Zavod za povijesne znanosti u Dubrovniku, Dubrovnik.

- Šverko, A., 2009: Ferme ornée Garagninovih u Divuljama kod Trogira. Radovi Instituta za povijest umjetnosti 33(1): 217-226.

- Trinajstić, I., 2008: Biljne zajednice Republike Hrvatske. Akademija šumarskih znanosti, Zagreb.

- Tutin, T. G., Heywood, V. H. , Burges, N. A. , Valentine, D.H. , Walters, S.M., Webb, D.A., (ed.)1964-1980, 1993: Flora Europaea 1-5. Cambridge University Press, United Kingdom.

- Turland, N. J., J. H. Wiersema, F. R. Barrie, W. Greuter, D. L. Hawksworth, P. S. Herendeen, S. Knapp, W.-H. Kusber, D.-Z. Li, K. Marhold, T. W. May, J. McNeill, A. M. Monro, J. Prado, M. J. Price, G. F. Smith (Eds.), 2018: International Code of Nomenclature for algae, fungi, and plants (Shenzhen Code) adopted by the Nineteenth International Botanical Congress Shenzhen, China, July 2017. Regnum Vegetabile 159. Glashutten: Koeltz Botanical Books. https://www.iapt-taxon.org/nomen/main.php./

- Visiani, R., 1863: Sulla vegetazione e sul clima dell'isola di Lacroma in Dalmazia. Coen, Trieste.

- Wawra H., Fr. Abel, 1886: Bougainvillea. Wiener Illustrierte Garten-Zeitung 19(1): pp 457-458.

- Wawra, H., 1866: Botanische ergenbnisse der reise Seiner Majestät des Kaisers Von Mexico Maximilian I. nach Brasilien (1859-60). Druck und Verlag von Carl Gerold’s Sohn, Wien, pp 11.

- The Plant List http://www.theplantlist.org/ (accessed: January $08,2020)$ 
- Wawra, H., 1875: Über die Eucalyptus - Anpflanzung in Pola. Österreichische botanische Zeitschrift, 25(1): 25-26.

Archival documents (Arhivski izvori)

- Archivio di Stato di Trieste (AST), Amministrazione Castello di Miramare (1851-1930), N 30, f 74 Documentazione contabile della cassa dell' arciduchessa Carlotta, nn 4-370, 1859-60.

- Archivio di Stato di Trieste (AST), Amministrazione Castello di Miramare (1851-1930), N 31, f 75 Documentazione contabile della cassa dell' archiduchessa Carlotta nn 373-1233, 1861-62.

- Archivio di Stato di Trieste (AST), Amministrazione Castello di Miramare (1851-1930), N 32 f 76 Documentazione contabile della cassa degli arciduchi, nn 1-69, 1863.
- Archivio di Stato di Trieste (AST), Amministrazione Castello di Miramare (1851-1930), N 33, f 77 Documentazione contabile della cassa degli archiduci, nn 70-143, 1863.

- Archivio di Stato di Trieste (AST), Amministrazione Castello di Miramare (1851-1930), N 34, f 78 Documentazione contabile della cassa degli arciduchi, nn 144-237, 1863.

- Archivio di Stato di Trieste (AST), Amministrazione castello di Miramare (1851-1930), N 48, f 95 Registro „Prima nota“185767.

- Österreichische Staatsarchiv, AT-OeStA/HHStA PFF GDPFF SR 40-1 Lacroma: Verwaltung nach Kronprinz Rudolf, 1890-1909, AT-OeStA/HHStA PFF GDPFF SR 40-1.

\section{SAŽETAK}

Cilj je ovog istraživanja u okviru ornamentalnih lokrumskih vrtova, a temeljem izvornih arhivskih dokumenata pohranjenih u Državnom arhivu u Trstu (AST) i Državnom ahivu u Beču (OeStA), po prvi puta napraviti jedinstveni popis planski sađenih hortikulturnih biljnih svojti iz razdoblja uprave nadvojvode Ferdinanda Maksimilijana Habsburgškog na otoku Lokrumu (1859-69). Nadalje, cilj rada je prikazati u kojem omjeru su se danas očuvale planski sađene hortikulturne vrste iz Maksimilijanova vremena. Hortikulturne vrste u smislu ovog istraživanja, podrazumijevaju ne samo popise ukrasnih vrsta drveća i grmlja, nego i povrća, voća te zeljastih trajnica koje su sađene u tom razdoblju. Zbog vrijedne graditeljske baštine otok Lokrum (72 ha) je u cijelosti zajedno s povijesnom jezgrom Dubrovnika 1979. godine uvršten na listu svjetske kulturne baštine UNESCO. U biljnogeografskom pogledu Lokrum pripada eumediteranskome području vazdazelenih šuma i makije hrasta crnike reda Quercetalia ilicis Br.-Bl. (1931) 1936 (Ilijanić i Hećimović 1989). U tablici 1 skupno su prikazani rezultati popisa bilja iz Maksimilijanovog razdoblja te inventarizacije sadašnjeg stanja. Ukupno je inventarizirano 256 svojti od čega 225 vrsta, 1 podvrsta, 3 varijeteta, 8 križanaca (hibrida) i 19 kultivara. Svojte pripadaju u 179 različitih rodova iz 80 porodica. Iz Maksimilijanova razdoblja utvrđeno je 213 svojti, od čega 184 vrste, 4 varijeteta, 8 križanaca i 17 kultivara. Alohtonih, egzotičnih svojti je bilo 193, od čega najviše s područja Srednje i Južne Amerike 66, azijskih vrsta 47, Australije 21, s Afrike 17 te s područja $\mathrm{Sj}$. Amerike 13. Prema skupinama biljaka najviše je bilo trajnica (50; $23,5 \%)$, slijede bjelogorične (26) i crnogorične stablašice (22, ukupno 48; 22,5\%) te grmolike $(44 ; 20,1 \%)$, dok je danas od ukupno 71 svojte (koja pripada u 43 porodice i 64 roda) prema inventarizaciji utvrđeno najviše grmolikih (20;28,2 \%), slijede bjelogorične stablašice (12) i trajnice $(12 ; 16,9 \%)$.

U arhivskim popisima se nalazi 20 svojti autohtonih u Hrvatskoj. Pri tome je broj autohtonih svojti bio izgledno veći, no u povijesnim dokumentima se u većini slučajeva pratila isključivo introdukcija egzota. Na Lokrumu su tada po prvi puta na ovome dijelu Jadrana introducirane sljedeće svojte; Ananas comosus, Musa $\times$ paradisiaca, M. acuminata, Eucalyptus diversifolia, E. globulus, Araucaria araucana, A. columnaris, A. angustifolia, A. bidwillii, A. cunninghamii, Bougainvillea spectabilis i Citrus reticulata. Od ukupno utvrđenih 51 ornamentalnih alohtonih svojti danas što je četvrtina u odnosu na Maksimilijanovo razdoblje, tek je 21 očuvana tj. ima kontinuitet iz tog vremena. Također, utvrđeno je da je danas na prostoru ornamentalnih vrtova prisutno 20 autohtonih svojti (od toga je 9 autohtonih ostalo prisutno iz Maksimilijanovog doba). Veći udio alohtonih egzotičnih biljaka nije uspio opstati zbog izostanka intenzivnog održavanja vrtova. Prema inventarizaciji 2018.-2019., danas je u okviru ornamentalnih vrtova na Lokrumu inventarizirana 71 svojta, koja pripada u 43 porodice i 64 roda. Na otoku su danas prisutne 3 invazivne vrste: Nicotiana glauca, Robinia pseudoacacia i Opuntia ficus-indica. Otok Lokrum je danas u cijelosti zaštićen kao posebni rezervat šumske vegetacije uključivo područje ornamentalnih vrtova iz Maksimilijanova razdoblja. Prema tomu bi eventualna reintrodukcija određenih svojti trebala biti sukladna ekološkim, fitocenološkim i krajobraznim značajkama područja Lokruma. Pri obnovi vrtova trebala bi se razmatrati selektivna reintrodukcija, onih svojti koje značajno doprinose obnovi stilskih karakteristika ovih vrtova u vremenu u kojem su stvarani. Pri tome isključujući sve invazivne, ali i potencijalno invazivne svojte koje nisu na službenim popisima invazivnih biljaka, poput svojti iz roda Pittosporum, Mesenbriamthemum, Acacia i dr. Ovdje objavljen popis svojti ornamentalnih Maksimilijanovih vrtova iz arhivskih izvora, bit će polazište za proces obnove koji ove vrtove očekuje.

KLJUČNE RIJEČI: vrtovi otoka Lokruma, Dubrovnik, Maksimilijan Habsburški, introdukcija, alohtone hortikulturne vrste, botanička analiza 